\title{
Flashmob i lærerutdanninger - studenters erfaringer med å skape dans sammen
}

\author{
Hilde Rustad ${ }^{1 \star}$ og Tonje Fjogstad Langens ${ }^{2}$ \\ ${ }^{1}$ Norges idrettshøgskole og ${ }^{2}$ OsloMet - Storbyuniversitetet
}

\begin{abstract}
Sammendrag
Denne artikkelen handler om lærerstudenter og deres erfaringer knyttet til gjennomføring av flashmob som studentdrevet danseprosjekt. Artikkelen undersøker sammenhenger mellom flashmobprosjektet og utviklingen av lærerstudentenes profesjonspersonlige kompetanse. Forskningsmaterialet utgiøres av studenttekster fra to kroppsøvingslærerutdanninger: årsstudium i kroppsøving ved OsloMet storbyuniversitetet og faglærerutdanningen i kroppsøving og idrettsfag ved Norges idrettshøgskole. Forskningsprosjektet er kvalitativt og har en hermeneutisk-fenomenologisk tilnærming. Gjennom analyse av studentenes besvarelser kom forfatterne fram til fire temaer: "følelser», "å skape dans", «nærhet og samarbeid» og «lærerrollen». Gjennom en profesjonsfaglig drøfting av disse temaene viser artikkelen blant annet hvordan flashmobprosjektet har relevans i et lærerutdanningsperspektiv ved at studenterfaringene kan knyttes til selvbestemmelse, medbestemmelse og solidaritet. Det framkommer tydelige sammenhenger mellom studentenes erfaringer og profesjonspersonlig kompetanse; flashmobprosjektet trer fram som et profesjonspersonlig dannelsesprosjekt som kan bidra til å gi studentene en kroppslig forankret autoritet.
\end{abstract}

Nøkkelord: Profesjonspersonlig kompetanse; kroppsøving; studentdrevet undervisning

\begin{abstract}
Flashmob in teacher education - students' experiences in creating dance together

This article is about physical education teacher students and how they experienced participating in a student-led flashmob dance project. The research examines connections between the flashmob project and the teacher students' profession-personal competence, and the research material consists of students' texts in which they have written about their flashmob experiences. The flashmob project was part of the program at two different teacher education institutions in Oslo: Oslo Metropolitan University and the Norwegian School of Sport Sciences. The research approach is hermeneuticphenomenological, and through thematic analysis the following four themes were identified: "feelings", "to create dance", "getting to know each other better and cooperate", and "teacher perspective". Through a profession-based discussion the article further shows how the flashmob project is highly relevant in a teacher education perspective as the students' experiences can be understood as closely connected with profession-personal principles as well as with selfdetermination, codetermination and solidarity. In addition, the flashmob dance project serves to provide physical education teacher students with bodily anchored authority.
\end{abstract}

^Korrespondanse: Hilde Rustad, epost: hilde.rustad@nih.no

(C) 2019 H. Rustad og T. F. Langens. This is an Open Access article distributed under the terms of the Creative Commons Attribution 4.0 International License (https://creativecommons.org/licenses/by-nc/4.0/), allowing third parties to copy and redistribute the material in any medium or format and to remix, transform, and build upon the material for any purpose, even commercially, provided the original work is properly cited and states its license.

Citation: H. Rustad og T. F. Langens. "Flashmob i larerutdanninger - studenters erfaringer med à skape dans sammen". Fournal for Research in Arts and Sports Education, Special Issue: «Kroppsøvingsfaget i bevegelse»Vol. 3(2), 2019, pp. 46-61. http://dx. doi. 46 


\section{Keywords: Profession-personal competence; physical education; student-led teaching}

Received: October, 2018; Accepted: June, 2019; Published: November, 2019

\section{Innledning}

Denne artikkelen handler om lærerstudenter og deres erfaringer knyttet til gjennomføring av flashmob som et studentdrevet danseprosjekt ved to lærerutdanninger i Oslo: årsstudium i kroppsøving ved OsloMet - storbyuniversitetet (OsloMet) og faglærerutdanning i kroppsøving og idrettsfag (FKI) ved Norges idrettshøgskole (NIH). Dans har en sentral posisjon i læreplanen for kroppsøving, Kunnskapsløftet (LK06), og er nevnt i kompetansemålene for hele skoleløpet (1-13). I formålet for kroppsøving framheves dans som en del av allmenndannelse og identitetsskaping (Udir, 2015). Dansens sentrale plass innebærer at kroppsøvingslærere må ha undervisningskompetanse i dans, og er derfor også en viktig del av lærerutdanninger (Rustad, 2017).

Nyere forskning viser imidlertid at kroppsøvingslærere i liten grad underviser dans (Moen, Westlie, Bjørke \& Brattli, 2018; Arnesen, Leirhaug \& Aadland, 2017; Moen, Westlie, Brattli, Bjørke \&Vaktskjold, 2015). Dette korresponderer med hvordan mange kroppsøvings-lærerstudenter oppgir at de har liten erfaring med dans fra egen skolegang (Rustad, 2017). Lærerstudentenes manglende eller begrensede erfaring med dans som en aktivitet $\mathrm{i}$ kroppsøving $\mathrm{i}$ egen skolegang kan forstås som årsak til at studenter kan ha en negativ holdning til dans i kroppsøvingslærerutdanningen, og at mange ikke gjenkjenner dans som en sentral del av kroppsøvingsfaget. Det er i denne konteksten at vi som lærerutdannere og forskere har utviklet flashmob som et studentdrevet danseprosjekt. Forskning (MacLean, 2007) viser at erfaring med dans i studieløpet spiller en rolle for hvorvidt studenter senere, som lærere, vil undervise dans, og dermed bidra til å gjøre gapet mellom læreplan og det som skjer i undervisningsrommet mindre. Dette støttes av Rebullido \& Lamerios (2016) forskning som viser at flashmob kan være et egnet alternativ til å gi studenter danseerfaring, ferdigheter og erfaring med kreative koreografiske prosesser, i tillegg til å skape samhold og øke motivasjon for dans. Når det gjelder forskning på danseflashmob i kroppsøvingslærerutdanning er Rebullido \& Lamerios spanskspråklige artikkel den eneste vi har kunnet finne.

I vår artikkel spør vi, som lærerutdannere og forskere: Hvilke erfaringer gjør lærerstudenter i gjennomføringen av flashmob som danseprosjekt, og hvordan kan erfaringene forstås i sammenheng med utdanningen av kroppsøvingslærere? Vi undersøker dette ved å se på sammenhenger mellom flashmobprosjektet og utviklingen av lærerstudentenes profesjonspersonlige kompetanse.

Vi starter med å redegiøre for Helle Winthers (2012) begrep profesjonspersonlig kompetanse, som er egnet til å besvare artikkelens forskningsspørsmål. Begrepet kan anvendes analytisk både for å få fram kunnskap om lærerstudenters erfaringer og utvikling fra student til lærer, og fordi det også omhandler hvordan det personlige spiller inn i et lærerutdanningsløp. Vi fortsetter med å redegjøre for flashmob som fenomen, og å beskrive våre flashmobprosjekt. Deretter presenterer vi metode, 
analyse og fortolkning, studentenes erfaringer inndelt i temaer, profesjonsfaglig drøfting og avslutning.

\section{Profesjonspersonlig kompetanse}

Profesjonspersonlig kompetanse handler om å sette fokus på kroppen som klangbunn for lederskap, og innehar følgende tre gjensidig avhengige prinsipp:

Egenkontakt: Kontakt til egen kropp og personlige følelser, evnen til å være fokusert og nærværende, evnen til å ha hjertet med seg og samtidig bevare et profesjonelt fokus og en privat avgrensning.

Kommunikasjonslesing og kontakterne: Evnen til å se, lytte, sanse og merke. Evnen til å lese både den verbale og kroppslige kommunikasjon. Evnen til å skape tillitvekkende kontakt med andre. Evnen til å sette grenser.

Lederskap over gruppe eller situasjon: Profesjonelt overblikk, utstråling, sentrering, klart lederskap over gruppe eller situasjon. Evnen til å innta eller holde et rom med en sunn og kroppslig forankret autoritet (Winther, 2012, s. 80, vår oversettelse).

Jørgensen, Winther, Nielsen \& Nybo (2018) hevder at det er det dynamiske samspillet mellom disse tre prinsippene som gjør at pedagogen vokser som underviser.

\section{Flashmob som danseprosjekt i to lærerutdanninger}

Flashmob kan defineres for eksempel som en semi-spontan engangshendelse som oppstår når en gruppe mennesker, kjente eller ukjente for hverandre, kommer sammen og kollektivt framfører en uvanlig eller oppmerksomhetsvekkende aktivitet, eller skaper en scene i offentlig rom i samsvar med forhåndsbestemte instruksjoner, for så å forsvinne igjen (Salmond, 2010, vår oversettelse). Flashmob kan innebære å rope slagord, spille instrumenter, danse, eller annen aktivitet. Flashmob er planlagt og forberedt, annonseres ikke på forhånd og skjer uventet og overraskende for alle som ikke selv deltar. I skolesammenheng kan flashmob innebære å lage en koreografi som danses på steder utenfor kroppsøvingssalen, som for eksempel i kantina, skolegården, eller gågata.

I forkant av høstsemesteret 2017 utvekslet vi erfaringer om undervisning i dans $\mathrm{i}$ kroppsøvingsfaget, og dette førte til at vi begge gjennomførte flashmob som studentdrevet danseprosjekt høsten 2017 ved våre respektive arbeidssteder. Flashmobprosjektet inngikk som del av den obligatoriske undervisningen i dans. Følgende krav ble stilt: 1) Flashmob skulle være et studentdrevet prosjekt, 2) Alle studentene skulle være deltagende i å skape dansen sammen, og 3) Flashmob skulle avslutningsvis framføres et annet sted enn i kroppsøvingssalen. I undervisningen ble studentene introdusert for flashmob gjennom følgende definisjon: «En flashmob er en gruppe mennesker som plutselig samles på et offentlig sted, der de sammen utfører en uvanlig og ofte morsom handling, for deretter å spre seg igjen» (Wikipedia). Studentene ble oppfordret til å sette seg inn i hva flashmob er på egenhånd, og de fikk tilgang til eksempler på flashmob gjennom flere internettlenker. På de to utdanningsinstitusjonene hadde 
gjennomføringen av flashmobprosjektet relativt ulike forløp. Et fellestrekk var at vi begge innimellom stakk innom studentene og var tilgjengelige for spørsmål. Dette førte til at vi fikk innblikk i prosessen, og innblikkene fungerte senere som klangbunn med hensyn til fortolkning av studenterfaringene.

\section{OsloMet-prosjektet}

Ved OsloMet ble flashmobprosjektet ledet av Tonje Fjogstad Langnes og gjennomført i første semester med studenter på årsstudium i kroppsøving. Studentene hadde totalt 16 undervisningstimer i dans. I første time ble de introdusert for flashmobprosjektet, som var integrert i hele den åtte uker lange undervisningsrekken hvor fokus var å øke studentenes erfaring og undervisningskompetanse i dans. De ble introdusert for ulike danser med fastlagte trinn, de lagde små soloer og danser i grupper, samt underviste hverandre i dans. Studentene ble oppfordret til å innlemme alle elementene i sin flashmobkoreografi. Gjennom hele perioden ble det satt av tid (fra 15 til 45 minutter) til å jobbe med deloppgaver knyttet til flashmobprosjektet. De siste dobbelttimene var øremerket ferdigstilling og framføring. Flashmobprosjektet var obligatorisk, men de kunne selv velge hvor mye og på hvilken måte de deltok. Flashmobkoreografien ble utformet av alle studentene i klassen, men to kvinnelige studenter påtok seg et mer overordnet ansvar.

Allerede første undervisningsdag ble studentene introdusert for tanken om at framføringen av flashmobben skulle foregå utenfor kroppsøvingssalen på et offentlig sted. Dette skapte spenning i studentgruppa. Mange uttrykte engstelse for å vise flashmobben for utenforstående, og gjennom undervisningsperioden ble derfor muligheten for at flashmobben eventuelt kunne gjennomføres i kroppsøvingssalen holdt åpen. Dagen før framføringen bestemte studentene at lærerutdanneren skulle bestemme framføringssted. Flashmobben ble bestemt framført i fellesarealet «P52 studenthallen» for studenter og ansatte, og det ble satt opp musikkanlegg. Studentene ankom rommet i puljer og plasserte seg tilfeldig ved ulike bord for å skjule for utenforstående at noe skulle skje. Overraskelsen var derfor stor blant de tilstedeværende da musikken kom på og åtte studenter begynte å danse. Etter hvert ble alle studentene med. De vekslet mellom å danse alle sammen samtidig, at bare jentene danset, at bare guttene danset, og at de danset i par. De avsluttet med å klappe i takt med musikken før de forsvant ut av rommet for oppsummering og feiring med boller og brus. Studentene danset i 3 minutter og 54 sekunder til en selvlagd «mash-up» bestående av fire sanger.

\section{NIH-prosjektet}

På NIH ble flashmobprosjektet ledet av Hilde Rustad som tidligere hadde gjennomført flashmob i FKI også i 2015 og $2016^{1}$. Flashmob ble gjennomført med bachelorstudenter i FKI, i studentenes 5. semester. Studieemnet «Dans og lek som erfaring og undervisningsfag» startet med 12 dobbelttimer som lå $\mathrm{i}$ forkant av at studentene

${ }^{1}$ Flashmobprosjektet var inspirert av pedagoger som tidligere hadde undervist på NIH, men selve oppgaven var helt annerledes. 


\section{H. Rustad og T. F. Langens}

skulle ut å undervise i skolen, og fokus var på fagdidaktikk og undervisningsinnhold. Etter skolepraksisperioden handlet det om å tilegne seg bredere erfaring i dans. Studentene arbeidet med å skape dans - først alene med solodans, så som flashmobprosjekt med hele klassen. Solodansoppgaven innebar at studentene fikk undervisning og veiledning innledningsvis, for deretter å fortsette som individuelt studentdrevet arbeid. Solodans og flashmob kan ses som en sammenhengende prosess hvor studentene først laget dans alene, etterfulgt av at hele klassen laget koreografi sammen som flashmob. Studentene kunne trekke bevegelsesmateriale de hadde laget i solokoreografiene med inn i flashmobarbeidet. Både solodans og flashmob var studentdrevet aktivitet og praktiske arbeidskrav.

På den digitale læringsplattformen Canvas ble det lagt ut en oppgavetekst med kriterier for godkjenning: «Flashmob skal inneholde: forflytning - ulike nivåer temposkift/bruk av ulike rytmer - repetisjon - begynnelse/midtdel/avslutning - synkron dans og ikke- synkron dans", og forslag til hvordan studentene kunne gå fram for å lage flashmobdansen. Forslaget innebar at studentene først kunne arbeide to og to sammen, så i mindre grupper, deretter litt større grupper, og til sist hele klassen sammen, og at de hele veien kunne akkumulere materiale. Studentene fulgte til dels forslaget og en student beskriver arbeidsprosessen slik:

Vi delte inn i 4 grupper der alle skulle komme opp med fire 8-tellinger hver. Deretter gikk gruppe en og to sammen og tre og fire og lærte trinnene til hverandre. Så gikk alle sammen og vi la alt sammen til en hel dans. Vi øvde en hel del på de ulike delene og hele dansen med og uten musikk.

Selve flashmobframføringen fant sted i kantina for studenter og ansatte klokka 12.00 fordi det erfaringsmessig er da de fleste studenter og ansatte spiser lunsj. Studentene plasserte seg «tilfeldig» rundt på forskjellige bord i en nærmest sirkelrund formasjon, og spiste sammen med de andre kantinegjestene. I det musikken de hadde valgt ble spilt over kantinas musikkanlegg reiste 36 studenter seg opp nesten samtidig. De begynte å danse først litt etter at musikken kom på, og danset synkront inntil dansen endte med at en student gjorde baklengs salto mens de andre studentene var i ro. Studentene danset i 1 minutt og 20 sekunder, og til stor applaus satte de seg deretter ned og spiste lunsj.

\section{Metode og forskningsmateriale}

Forskningsprosjektet er kvalitativt og har en hermeneutisk-fenomenologisk tilnærming. Ifølge Van Manen handler fenomenologi om å spørre «What is this or that kind of experience like?» (van Manen, 1990, s. 9). Et hermeneutisk perspektiv handler ikke bare om å forstå og fortolke, men også om å formidle. Et slikt perspektiv er anvendelig i skolekonteksten, og for å formidle unge voksnes opplevelser.

I dette prosjektet er lærerstudentenes flashmoberfaringer fenomenet som undersøkes og fortolkes. Forskningsmaterialet utgjøres av studenttekster. Studenttekstene er ikke identiske med selve erfaringene, men sier likevel noe om studentenes erfaringer. Vi stilte studentene følgende tre spørsmål som de besvarte digitalt: 
1. Beskriv din erfaring med FLASHMOB-prosjektet. Skriv så utfyllende som mulig om det å skape dans, det å danse selv, og gruppeprosessen. Ofte er ikke erfaringer entydige. Forsøk å få fram ulike sider ved erfaringene.

2. I hvilken grad vurderer du FLASHMOB som relevant i forhold til skole/undervisning? Hvorfor/hvorfor ikke?

3. Tenker du at FLASHMOB er noe du kan gjøre som framtidig lærer?

I alt skrev 62 studenter om sine erfaringer, 26 fra OsloMet og 36 fra NIH. Ved OsloMet skrev studentene om sine erfaringer direkte etter giennomført flashmob, mens NIHstudentene skrev først ei uke etter, fordi de hadde annen undervisning rett etter flashmobframføring. Lengden på studentenes erfaringsbeskrivelser varierer fra 1 til 188 ord.

Alle studenttekstene ble samlet $\mathrm{i}$ et felles dokument. Vi har giennomført en tema-analyse av studenttekstene, og ifølge van Manen er en slik analyse en åpen handling for å skape mening:

Making something of a text or of a lived experience by interpreting its meaning is more accurately a process of insightful invention, discovery or disclosure-grasping and formulating a thematic understanding is not a rule-bound process but a free act of seeing meaning. (van Manen, 1990, s. 79)

In exploring themes and insights, we can treat texts as sources of meaning at the level of the whole story; at the level of the seperate paragraph; and at the level of the sentence, phrase, expression, or single word. (van Manen, 2014, s. 320)

Hvert tema er et redskap for å "get at the notion of what we are adressing", og noe som gir kontroll og orden i forskning og skrivearbeid (van Manen, 1990, s. 79). I tråd med van Manen kom vi gjennom lesing og gjenlesing av studenttekstene fram til følgende fire temaer: «følelser», «å skape dans», "nærhet og samarbeid» og "lærerrollen». Temaene vokste fram ved at vi møttes og leste tekstene sammen og diskuterte med hverandre hvordan vi forstod studentenes erfaringer. Underveis markerte vi tekstdeler med fire forskjellige farger, en for hvert tema. Etter hvert som temaene ble tydelige, styrte de vår videre lesning og skapte struktur og orden. Det er imidlertid viktig å påpeke at vi forstår temaene også som overlappende.

I forkant av at studentene skrev om sine erfaringer fikk de informasjon om prosjektets hensikt, og at det var frivillig å delta. De ble informert om at deltakelse eller fravær av deltakelse ikke hadde noen konsekvenser for dem som studenter. Alle fikk tilsendt en online link til spørsmålene, og studentenes tekster er anonymisert og kan ikke spores tilbake til den enkeltes IP-adresse. Da det heller ikke ble samlet inn personidentifiserende opplysninger om studentene er forskningsprosjektet i følge retningslinjene til Norsk senter for forskningsdata (NSD) dermed ikke meldepliktig.

\section{Studentenes erfaringer}

Denne delen omhandler de fire temaene vi har identifisert $\mathrm{i}$ analysen; «følelser», «å skape dans», «nærhet og samarbeid» og «lærerrollen». Vi presenterer studenterfaringer og fortolkninger rundt erfaringene knyttet til hvert av temaene. 


\section{H. Rustad og T. F. Langens}

\section{Studentenens følelser knyttet til flashmobprosjektet}

I studenttekstene trer følelser tydelig fram som tema. Studentene bruker positivt ladede følelsesord som: morsomt, gøy, glad, mestringsfølelse, liker, spennende, givende, bra, utvidet komfortsone, fint, pondus, positivt, kreativt, grei, kul, grensesprengende, komfortabel, og negativt ladede følelsesord som: nervepirrende, utenfor komfortsone, flaut, kleint, vanskelig, skeptisk, kjedelig, utfordrende, håpløst, skummelt, rar stemning, litt traust. Det at følelser er så framtredende er interessant siden spørsmålene studentene fikk ikke direkte omhandler følelser. Vi har definert følelser som et eget tema, samtidig som vi forstår følelser som del av alle temaene. Studentene framhever flashmoberfaringen som følelsesladet, og de bruker gjennomgående ord som beskriver eller kan assosieres med følelser.

Følelser er alltid tilstede i undervisningsrommet. Mens en student beskriver hvordan "Det å danse flashmob var både skummelt og gøy", som vi tolker som positiv erfaring, beskriver mange studenter flashmoberfaringen som å ha både negative og positive sider. To eksempler på dette er:

Jeg synes flashmob var en svært ubehagelig opplevelse og jeg var ekstremt ukomfortabel i situasjonen. Prosessen inn mot selve dansen gikk bra, og alle fikk deltatt aktivt.

... jeg har egentlig vært veldig skeptisk omtrent gjennom hele prosessen. [...] Jeg ser at det skaper samhold gjennom diskusjoner og samarbeid. Til syvende og sist opplevde jeg det som gøy og lærerikt og ikke minst opplevde jeg mestringsfølelse.

En student reflekterer rundt hvordan flashmobprosjektet krever «at man i større grad tørr å slippe seg ordentlig løs, for at dansen skal bli ordentlig bra!», mens en annen beskriver prosjektet som grensesprengende.

Studenttekstene reflekterer med andre ord ulike følelser som tilstedeværende på forskjellige måter i prosessen. Flere studenter startet med å være skeptiske, men etterhvert som de jobbet sammen i mindre grupper, og senere med hele klassen sammen, utviklet de et positivt forhold til oppgaven. Dette kom tydeligst til uttrykk i tekstene til OsloMet-studentene, som jobbet med flashmobprosjektet over en lengre periode enn NIH-studentene. NIH-studentene hadde kun 6 timer til å lage og øve på sin flashmobkoreografi og måtte være effektive, men i og med at oppgaven kom i etterkant av et soloarbeid hadde hver student et dansemateriale som han eller hun kunne trekke med seg inn. Studentene hadde ulik kompetanse i dans, og for at alle skulle kunne være komfortable måtte koreografien være enkel slik at alle kunne mestre den. Tidsperspektivet spilte med andre ord inn med hensyn til hvordan studentene erfarte prosessen.

Videre trekker studentene fram «holdning» som en forklaring på hvorfor flere var skeptiske til flashmoboppgaven. En skriver «mye [har nok] å gjøre med holdningen jeg gikk inn i dette med» og en annen uttrykker at det som var slitsomt var «negativitet og motvilje» hos andre studenter. Dette viser at studenter hadde bevissthet om hvordan både egen og andres holdning spilte en rolle for hvordan en slik gruppeoppgave erfares. 
Et viktig moment ved flashmobprosjektet var at visningen skulle foregå i institusjonens fellesarealer, og komme som en overraskelse for tilskuerne. Det å danse stedsspesifikt utenfor kroppsøvingssalen brakte opp ulike følelser i studentene. Flere syntes det var uproblematisk, og en beskriver det som å bli «pushet til å vise for andre enn klassen", mens en annen skriver "personlig tenkte jeg i utgangspunktet at å danse i P52 skulle gå fint, men hadde ingen aning om at det skulle bli så gøy!». Flere som i utgangspunktet var skeptiske gir uttrykk for overraskelse over hvor positiv selve visningserfaringen var, og over opplevelsen av mestring: «Det var litt nervepirrende å vite at vi skulle framføre, men det handlet om å gå ut av komfortsonen. Jeg synes det var kjempemoro!».

En NIH-student mente klassen valgte for enkle løsninger og at de kunne ha utfordret seg selv mer. Studenten skriver:

Selv synes jeg det var litt kjedelig at vi gjorde såpass enkelt, fordi jeg liker at danser man skal fremvise ser litt kule ut. Klassen lærte seg dansen relativt fort, så vi kunne nok egentlig gjort det litt vanskeligere for oss selv.

Studenten mener sannsynligvis at en vanskeligere koreografi ville ha imponert mer, og at de som dansere dermed ville ha framstått i et mer positivt lys. Studenten er med andre ord opptatt av hvordan han/hun framstår for andre. Dette kan ha stor betydning for den enkelte, og i et slikt perspektiv kan dans forstås som å handle om status.

Det at følelser er et framtredende tema kan tolkes som at det for mange studenter er meningsfylt og morsomt å lage dans, og å danse, sammen med andre studenter. Samtidig er det å vise dans for utenforstående skummelt, ubehagelig, utenfor komfortsonen og forbundet med nervøsitet. Flashmobprosjektet synes å ha vekket til dels sterke følelser hos studentene, og dette kan være en indikasjon på at flashmoberfaringen har satt dype spor og vært grensesprengende.

\section{Å skape dans sammen}

For mange studenter var det å skape, her forstått som å lage en koreografi sammen, en prosess de beskrev i positive ordelag. En student beskriver først det å skape dans som entydig positivt, "gøy og spennende», og deretter det at hele klassen skaper dans sammen, som givende. Studenten får fram at det å danse utløser glede, og framhever at det var "veldig morsomt å danse selv under øvelsene». Dette kan forstås som at det er den sosiale konteksten som utløser glede, og/eller at det er selve den kroppslige erfaringen av å være i bevegelse i dans, det gjelder. Studenten trer på denne måten fram i teksten som dansende subjekt.

Flere studenter peker på hvordan det å skape er koblet til kreativitet. En skriver: «Å skulle skape sin egen dans gir rom for kreativitet», og en annen «det er gøy å lage dans, men utfordrende å skape spennende bevegelser». For studentene er det ikke nok å lage dans, det stilles krav til at bevegelsene skal være spennende, og det er uklart hvorvidt "spennende» gjelder selve det å danse bevegelsene, eller at det skal være spennende å se på flashmobdansen. En mener at det å ha rammer har stor 


\section{H. Rustad og T. F. Langens}

betydning når dans skal skapes, mens en annen student skriver kortfattet om det «å skape» som «koreografi i fokus, mye forarbeid og dannet ny forståelse rundt hvordan å bygge koreografi». Studenten skriver analytisk og subjektløst, men på tross av dette er en nærliggende tolkning at det er nettopp studenten selv som har fått «ny forståelse» gjennom levd erfaring ved å delta i flashmobprosjektet.

Sitatet nedenfor får fram flashmob som en motsetningsfylt erfaring:

det er veldig gøy å danse. [...] jeg synes det er vanskelig å skape dans siden jeg ikke har så mye erfaring [...] andre kommer med bedre forslag enn meg [...] Det å danse, og danse $\mathrm{i}$ en stor gruppe er utrolig gøy. Å se hva oss som gruppe klarer å få fram og hvor flinke vi er til å få alle med i prosessen i forkant gjør at man får et skikkelig eierforhold. (Forfatternes utheving.)

Studentens refleksjon kan tolkes som å gjenspeile lav selvtillit relatert til begrenset danseerfaring. Samtidig er studenten opptatt av fellesskap og uttrykker dette gjennom pronomenene vi/oss/alle, som få andre studenter bruker i sine tekster. Det skinner gjennom at det å delta ga eierskap til dansen, uavhengig av om han/ hun var med på å skape dansen. Eierskap kommer også tydelig fram hos flere NIHstudenter som i samtaler med lærerutdanner samt i skriftlig innlevering fortalte at klassen på eget initiativ danset flashmobkoreografien i sosiale sammenhenger utenfor undervisningskonteksten.

\section{Nærhet og samarbeid i et studentdrevet danseprosjekt}

Mange studenter framhever at flashmob gjør noe med studentgruppa. I studenttekstene gjenspeiles dette blant annet $\mathrm{i}$ ord og ordkombinasjoner som kan knyttes til demokratiske prosesser: skaper samarbeid, samhold, diskusjoner, inkluderende miljø, ytre egne meninger, selvbestemmelse, deltagelse, enighet, demokratiske diskusjoner/ avgjørelser/prosess/deltakelse.

I mange studenttekster framheves betydningen av at hele klassen jobbet sammen som positiv. Flashmobprosessen ga på denne måten ny erfaring da studentene vanligvis arbeider i mindre grupper. For eksempel skriver noen: «Vi har vunnet mye på denne opplevelsen, og den har brakt klassen nærmere», "vi [har] lært hverandre bedre å kjenne», og om "samhold gjennom diskusjoner og samarbeid». Mange erfarte prosessen som inkluderende, og som å kunne bidra til «et inkluderende klassemiljø». Studentene er imidlertid ikke entydig positive til prosessen, og en skriver: «Jeg opplevde at når hele klassen skal komme opp med ideer samtidig blir det lite effektivt». Det å jobbe så mange sammen har vært utfordrende, og en student framhever det aller mest utfordrende som «det å komme ut av komfortsonen og det å bli enige om trinn som alle kan mestre».

Betydningen av at studentene har ulik danse-erfaring blir trukket fram, og to skriver om hvordan «vi som gruppe har tatt for oss varierende ferdighet og nivå, samt har vært med på å motivere hverandre til å delta» og «mange følte mestringsfølelse underveis og i etterkant». Når enkeltstudenter tok ledelsen var det rom for å komme med 
forslag: «Jeg og andre som ikke har noe særlig erfaring med dans fikk også komme med innspill og gjort forandringer slik at det ble lettere». Noen ergrer seg over at enkelte unnlater å ta ansvar, og en skriver «Mange blir gratispassasjerer, og det kan være vanskelig å få fremdrift i prosessen».

I flashmobprosjektet lærte studentene av hverandre, om hverandre og om seg selv knyttet til en skapende gruppeprosess. De kom nærmere hverandre og måtte forhandle om hvordan oppgaven skulle løses. Det at alle i klassen var involvert og tok ansvar sammen hadde stor betydning. Det var nytt for studentene å arbeide sammen som hel klasse med henholdsvis 26 og 36 studenter. I prosessen fikk studentene erfaring med hva som kreves når så mange skal samarbeide. Studentene forhandlet om posisjoner, hvor noen tok ansvar og andre ikke. Alle måtte innordne seg og gjøre det som skulle til for at fellesskapet kunne fungere. Prosjektet ga studentene verdifull erfaring med mulighet for personlig utvikling både individuelt og som del av et fellesskap.

Det å være mange muliggjør at enkeltindividet blir mindre synlig, og en student framhever nettopp som positivt at for de med liten danseerfaring er det «lettere å være en i mengden». Samtidig vil grupper i denne størrelsesordenen kunne føre til at enkelte kan føle seg utenfor. Selv om intensjonen er at alle skal bidra og delta, er det ikke nødvendigvis det som skjer, og graden av tilhørighet studentene føler til fellesskapet vil variere.

\section{Studentenes lærerrolleperspektiv på flashmob}

Mange av studentene uttaler seg tydelig ut fra et lærerrolleperspektiv, og reflekterer rundt flashmobprosjektets anvendelighet og muligheter i skolesammenheng. Eksempler er "[flashmob] gir elevene eierskap til dansen", «Jeg kan se for meg at et tverrfaglig samarbeid med musikk vil fungere bra», "For et slikt prosjekt er det viktig med en ressurssterk klasse og en klasse som tar ansvar», og noen studenter koblet også flashmobprosjektet til læreplanen i kroppsøving. I analysen skilte dette materialet seg ut ved at studentene tydelig skrev ut fra rollen som lærer, mens de i delene av studenttekstene som ligger til grunn for de andre temaene oftest skrev ut fra seg selv som student og som erfarende subjekt.

Det at flashmobprosjektet var studentstyrt vurderes av flere studenter som overførbart til elevstyrt undervisning, og en skriver:

Metoden egner seg for å skape elevmedvirkning gjennom å la elevene lage dansen sammen. Dette skapte også stor motivasjon i gruppen. I tillegg kan elever lære nye bevegelser av hverandre, noe som er positivt for elevens kroppserfaring.

Flashmobprosjektet forstås også som egnet til å skape godt klassemiljø. En skriver «i tillegg skaper man noe sammen som kan gi en tilhørighet og trygghet i en klasse. Man kommer tettere sammen». En annen framhever hvordan det at elevene sammen skaper dans «åpner for selvbestemmelse og medbestemmelse», og kan «gi elevene en større følelse av eierskap, enn om læreren lager koreografien». Samtidig trekker noen studenter fram betydningen av elevenes holdning til dans: 
Det vil være vanskelig å involvere alle elevene og å holde styr på de som stritter imot. Det kan også være sosiale aspekt som fører til at elevene (kanskje spesielt gutter) ikke vil ta ansvar for dansen da det ikke er sosialt akseptert.

I dette sitatet synliggiøres både en antagelse av at elever vil ha motstand mot dans, og at dans er en «jenteaktivitet». Et annet eksempel er en student som skriver «det kan være litt vanskelig når noen hater dans».

Når en student skriver motsetningsfylt om dans som både fint og inkluderende, men også at det «å måtte presentere dansen i et miljø som skaper usikkerhet og mye nerver kan være uheldig», tolker vi dette dithen at det er det å danse for andre studenten mener kan gjøre skoleelever usikre. Dette kan forstås som å gjenspeile studentens egen erfaring med flashmobprosjektet, og at nettopp det å utsette seg for andres blikk er noe denne studenten er ukomfortabel med.

\section{Profesjonsfaglig drøfting knyttet til profesjonspersonlige prinsipper}

Med flashmobprosjektet blir studentene kastet inn i en skapende samarbeidsprosess hvor vi forstår de profesjonspersonlige prinsippene som å bli aktivert. Som nevnt innledningsvis innehar profesjonspersonlig kompetanse tre giensidig avhengige prinsipp: «egenkontakt», «kommunikasjonslesing og kontaktevne», og "lederskap over gruppe eller situasjon" (Winther, 2012).

Egenkontakt handler om følelser og har betydning for selvutvikling. I alle mellommenneskelige relasjoner og undervisningsrom, som i skolen og i lærerutdanninger, er følelser til stede (Winther \& de Jong, 2016). Følelser som settes i sving kan gi muligheter og utgiøre begrensninger. Positive følelser som glede og tilhørighet skaper muligheter og kan virke befriende og forløsende. Negative følelser knyttet til at noe oppleves som ukomfortabelt, flaut eller skummelt kan virke hemmende, samtidig som det å håndtere slike følelser forstås som nært knyttet til personlig utvikling. Det er i skjæringspunktet mellom det skumle og det morsomme at unge drives til å strekke seg litt lengre og gjøre ting de på forhånd ikke trodde at de torde (Sandseter, 2010; Winther \& de Jong, 2016). Winther (2008) skriver om hvordan dans kan handle nettopp om å flytte grenser, og at dette kan forstås i et selvutviklingsperspektiv. Dette støttes av Rønholt (2014) som påpeker at følelsesinntrykk og uttrykk er viktig for utvikling av personlig kompetanse.

Flashmobprosjektet utløste både positivt og negativt ladede følelser. For lærerstudenter er det viktig å oppleve og erfare følelsessituasjoner for gjennom egen erfaring å tilegne seg innsikt i elevenes mulige følelser, og hvordan følelser kan påvirke læringssituasjonen. Winther \& de Jong (2016) framhever nettopp følelsesmessige prosesser som viktige kjennetegn på læring. Flashmobprosjektet har vært følelsesmessig grenseoverskridende for mange, og gjennomføringen har bidratt til mestring og høyere selvtillit hos studentene når det gjelder å danse, og å danse foran andre. MacLean (2007) har vist at økt selvtillit knyttet til dans i lærerutdanning er en faktor som øker sannsynligheten for at studentene, som lærere, vil undervise dans. Uavhengig av hvorvidt lærerstudentene 
opplevde flashmobprosjektet som suksess eller fiasko, eller noe derimellom, vil erfaringene kunne ha betydning for utvikling av deres profesjonspersonlige kompetanse og øke sannsynligheten for at de vil undervise i dans som ferdigutdannede lærere.

Kommunikasjonslesing er sentralt for alle som jobber med mennesker, og kroppen kommuniserer alltid (Winther, 2012). Gjennom kroppen uttrykkes blant annet engasjement, følelser og relasjonsforhold. Gjennom flashmobprosjektet skapes erfaringen relasjonelt. Meningsskapingen skjer ikke i studentene som adskilte subjekter, men mellom dem. De skaper dans, og dermed mening, sammen. I flashmobprosjektet utfordres studentenes evne til kommunikativ lesing, kontaktevne og lederskap. Flashmob som studentdrevet prosjekt stilte krav til studentenes evne til samarbeid, inkludering, deltakelse, forhandling om hvordan å ta avgjørelser, vise tillit og ta ansvar. Studentene fikk øve seg på å avlese hverandres kroppslige kommunikasjon gjennom å se, lytte og være i bevegelse på en og samme gang, noe som er sentrale elementer for å utvikle profesjonspersonlig kompetanse.

Når studentene skriver om følelser knyttet til det å bli sett som dansende av andre kan kroppen forstås som å stå i forgrunnen. Dette berører et annet sentralt kompetanseområde for kroppsøvingslærere som handler om nødvendigheten av å ville bli sett, det å kunne rette elevenes oppmerksomhet mot en selv, og det å kroppslig innta og holde et rom. Winther (2012) skriver om kroppslig forankret autoritet som noe som innebærer en fornemmelse av nærvær, fokus, styrke og balanse selv i utfordrende situasjoner. Denne typen lederskap innebærer på den ene siden å kunne påkalle oppmerksomheten og ta plass, og på den andre siden å gi plass for elevene. Nettopp ved å erfare å danse og samtidig bli sett av andre, oppøves en kroppslig forankret autoritet. En slik autoritet synliggjøres gjennom tydelig tilstedeværelse i undervisningssituasjonen og bidrar til å skape et godt læringsmiljø.

Kunnskap om kroppen og det kroppslige er sentralt i kroppsøvingsfaget, og i læreplanens formål framheves det at faget skal «ruste elevene til vurdering av kroppsideal og bevegelseskulturer som kan påvirke selvfølelsen, helse, ernæring, trening og livsstil»(Udir, 2015). Det å ha kjennskap til ulike perspektiver på kropp og kroppslig mening framheves av Moen \& Rugseth (2018) som vesentlig for å nå målet om et inkluderende kroppsøvingsfag. Gjennom sine analyser av nasjonale styringsdokumenter for kroppsøving og kroppsøvingslærerutdanning framhever de at faglærutdanningen i kroppsøving «bidrar til å reprodusere en tatt-for-gitt-forståelse av kropp som trenbar og kontekstfri» og at «lærere, studenter og lærerutdannere i stor grad bygger sin forståelse av kropp(en) som et trenbart objekt ..." (Moen \& Rugseth, 2018, s. 165). Sett i relasjon til dette er det et interessant poeng at lærerstudentenes glede og læring knyttet til «å gjøre» flashmob som samarbeidsprosess om dans, viser hvordan de erfarer som dansende kroppssubjekt, samtidig som de - ved å danse for andre - føler bekymring knyttet til hvordan de framstår, og dermed forstår seg selv som kroppsobjekt for andres blikk. I lærerutdanningssammenheng er dermed flashmobprosjektet et egnet utgangspunkt for refleksjon rundt begrepene kroppssubjekt og kroppsobjekt. 


\section{H. Rustad og T. F. Langens}

Karlefors og Larsson (2018, s. 42) hevder at det er behov for å anvende ulike undervisningsmetoder i kroppsøvingslærerutdanningen. Denne tilnærmingen må ikke være for smal, men knyttes til det som skal læres og tilpasses heterogeniteten i elevmassen. Karlefors og Larsson (2018) etterlyser mer elevdrevet undervisning i kroppsøving. Vi argumenterer for at flashmob er et prosjekt som innfrir på flere av disse punktene, og at flashmob også er velegnet til å oppfylle deler av skolens danningsoppdrag. Gjennom flashmobprosjektet får studentene erfaring med studentdrevet undervisning, og de får ansvar for avgjørelser knyttet til erfaring og oppdagelse av ny kunnskap. Dette har overføringsverdi til skolekonteksten hvor elevene kan gis ansvar og medbestemmelse, samtidig som det kan stilles krav til hvordan oppgaven løses. Det å gi en studentstyrt, eller elevstyrt, gruppeoppgave som flashmob innenfor gitte rammer kan gi deltagerne øvelse i, og utvikle egenskaper knyttet til, selvbestemmelse, medbestemmelse og solidaritet, som forstås som grunnleggende egenskaper i et demokratisk samfunn. ${ }^{2}$

\section{Avslutning}

I denne artikkelen har vi undersøkt sammenhenger mellom flashmobprosjektet og utviklingen av lærerstudentenes profesjonspersonlige kompetanse med problemstillingen "Hvilke erfaringer gjør lærerstudenter i gjennomføringen av flashmob som danseprosjekt, og hvordan kan erfaringene forstås i kroppsøvingslærerutdanningssammenheng?». Vi har vist hvordan studentene gjorde erfaringer i en prosess preget av følelser der hele klassen sammen skapte dans. De utforsket og oppøvet evnen til nærhet og samarbeid, og mange gjorde refleksjoner ut fra et lærerrolleperspektiv.

Gjennom analyse av studenttekstene har vi funnet forbindelser mellom flashmobprosjektet, slik det er gjennomført i lærerutdanningene ved OsloMet og NIH, og utviklingen av kroppsøvingslærerstudentenes profesjonspersonlige kompetanse. Når det gjelder det første profesjonspersonlige kompetanseprinsippet egenkontakt viser studenttekstene hvordan studentene har jobbet med å komme i kontakt med seg selv og sin egen kropp gjennom å lage dans, danse selv, og danse for andre, og med sine personlige følelser knyttet til dette. I tillegg har de oppøvet evnen til å være fokusert og nærværende gjennom å arbeide sammen, og ved å være synlige i dans for hverandre og for andre, som dansende. For flere har nettopp det å danse for andre vært grensesprengende. Gjennom prosjektet kan studentene på denne måten forstås både som å ha måttet bevare et profesjonelt fokus, for at klassen skulle kunne gjennomføre oppgaven sammen, og som å ha hatt en privat avgrensing, i og med at mange har gitt utrykk for at de har kjent seg ukomfortable og engstelige ved tanken på å vise dans for andre enn medstudentene.

Sammenhengen til det andre prinsippet kommunikasjonslesing og kontakterne er svært tydelig. I samarbeid og samhandling i et skapende prosjekt har studentene

\footnotetext{
${ }^{2}$ Vi forstår de profesjonpersonlige prinsippene som relatert til Klafkis (2001) dannelsesbegrep.
} 
arbeidet med å utøve, se, lytte, sanse og merke. For å kunne gjennomføre flashmobprosjektet har de måttet lese både verbal og kroppslig kommunikasjon, og mange har måttet jobbe med seg selv, sin egen selvtillit og det å ha tillit til andre, og derigjennom håndtert eventuelle indre og ytre konflikter.

Når det gjelder det tredje prinsippet, lederskap over gruppe eller situasjon, er sammenhengen løsere. Studentene kom fram til løsninger på oppgaven som hel klasse, og de utforsket på denne måten - og i samsvar med oppgaven de hadde fått - hvordan lederskap kan utøves, men som demokratisk samarbeidsprosess. Studenttekstene får fram hvordan enkelte studenter allikevel utviste mer lederskap enn andre, uten at dette førte til konflikt.

Vi argumenterer for at flashmobprosjektet er egnet til å bevisstgjøre studenter i forhold til ulike kroppsperspektiv. Det å arbeide som kroppsøvingslærer innebærer å bli sett av andre i kroppslig utfoldelse. Ved å jobbe med skapende dans, ut fra studentenes erfaring og kompetanse, med eget bevegelsesmateriale og som studentdrevet aktivitet, kan studentene få positiv subjekterfaring som kan overskygge og gis større vekt enn bekymringen for hvordan kroppen som objekt framstår for andre. I et lærerutdanningsperspektiv forstår vi det å få erfaring med å vise dans og å bli sett dansende som betydningsfullt, da dette er erfaring som kan føre til økt selvtillit, hvilket igjen vil kunne ha avgjørende betydning for hvorvidt studenten som lærer vil undervise dans. Ved på denne måten $a$ gjøre dans gir flashmobprosjektet nyttig kunnskap ervervet gjennom kroppslig erfaring, og nettopp dette er et viktig bidrag til utviklingen av studentenes kroppslige forankrede autoritet knyttet til å utvise lederskap ved å innta og holde et rom.

Det vil være interessant $i$ et lignende framtidig forskningsprosjekt å, i tillegg til at studentene skriver om sine erfaringer, gjennomføre studentloggføring, intervjuer, video-observasjoner, samt lærerutdanneres deltagende observasjoner. Spørsmålene studentene svarte på i dette prosjektet er få, og studenttekstene gir et begrenset innblikk i flashmoberfaringene. Til tross for dette tror vi at det å skrive om egne erfaringer har gitt studentene økt bevissthet og dypere refleksjon med hensyn til flashmoberfaringen. Dermed er prosjektet i seg selv et bidrag som kan ha betydning for hvordan studentene senere som lærere vil undervise i dans.

Studenttekstene beskriver negative og positive erfaringer, og for oss som lærerutdannere er erfaringene med flashmob som studentdrevet skapende danseprosjekt i utdanningen ikke entydig. Flertallet av studentene var positive til flashmobprosjektet, og mange beveget seg fra negativ til positiv innstilling i løpet av prosessen. I et kroppsøvingslærerutdanningsperspektiv er flashmobprosjektet relevant; det trer fram som et profesjonspersonlig dannelsesprosjekt som i tillegg bidrar til å gi studentene nødvendig kroppslig forankret autoritet.

\section{Forfatteromtale}

Hilde Rustad er danseforsker, dansekunstner og pedagog, og ansatt som postdoktor ved Norges Idrettshøgskole. Rustad har en Nordisk Master i dansevitenskap (NO-MA-DS) fra 


\section{H. Rustad og T. F. Langens}

NTNU. Hun er utdannet danser og koreograf fra Kunsthøgskolen i Amsterdam, avdeling School for New Dance Development (SNDO). Rustad er styremedlem i Nordisk Forum for Danseforskning (NOFOD).

Tonje Fjogstad Langnes er førsteamanuensis ved Institutt for grunnskole- og faglærerutdanning ved seksjon for kroppsøving og idrettsfag ved OsloMet - storbyuniversitetet. Hennes forskningsinteresser er knyttet til områdene ungdomskultur, kroppsøving og dans i skolen, kjønn og etnisitet/mangfold. Langnes er utdannet faglærer i kroppsøving og idrettsfag, og har lang undervisningserfaring på både grunnskole- og høgskolenivå.

\section{Referanser}

Arnesen, T., Leirhaug, P. \& Aadland, H. (2017). Dans i kroppsøvingsfaget - mer enn gode intensjoner? fournal for Research in Arts and Sports Education, 1(3), 47-60. http://dx.doi.org/10.23865/jased.v1.635

Jørgensen, S. I., Winther, H., Nielsen, H. S., \& Nybo, L. (2018). "Authentic microteaching» som akademisk lærings- og undervisningsmodel. Dansk Universitetspaedagogisk Tidsskrift, 13(24), 55-68.

Karlefors, I., \& Larsson, H. (2018). Searching for the "how». Teaching methods in Swedish physical education. Scandinavian Sport Studies Forum, 9, 25-44. Hentet fra https://sportstudies.org/wp-content/ uploads/2018/02/025-044_vol_9_2018_karlefors-larsson.pdf

Klafki, W. (2001). Dannelsesteori og didaktikk - nye studier. Århus: Klim.

MacLean, J. (2007). A longitudinal study to ascertain the factors that impact on the confidence of undergraduate physical education student teachers to teach dance in Scottish schools. European Physical Education Review, 13(1), 99-116. https://doi.org/10.1177/1356336X07073075

Moen, K., \& Rugseth, G. (2018). Perspektiver på kropp i kroppsøvingsfaget i skolen og i faglærerutdanningen i kroppsøving. Fournal for Research in Arts and Sports Education, 2(1), 154-168. http://dx.doi.org/10.23865/ jased.v2.1052

Moen, K. M., Westlie, K., Bjørke, L., \& Brattli, V. H. (2018). Når ambisjon møter tradisjon: En nasjonal kartleggingsstudie av kroppsøvingsfaget $i$ grunnskolen (5.-10. trinn). Oppdragsrapport 1/2018, Elverum: Høgskolen i Innlandet. Hentet fra http://hdl.handle.net/11250/2482450

Moen, K. M., Westlie, K., Brattli, V. H., Bjørke, L., \& Vaktskjold, A. (2015). Kroppsøving $i$ Elverumskolen: En kartleggingsstudie av elever, larere og skolelederes opplevelse av kroppsøvingsfaget $i$ grunnskolen. Oppdragsrapport 2/2015. Elverum: Høgskolen i Hedmark. Hentet fra https://brage.inn.no/inn-xmlui/ handle/11250/300725

Rebullido, T. R., \& Lameiro, C.V. (2016). El Flashmob como propuesta de innovación educativa en expresión corporal y danza. Retos: Nuevas Tendencias En Educación Física, DeporteY Recreación, 29, 126-128. Hentet fra https://recyt.fecyt.es/index.php/retos/article/view/35394

Rustad, H. (2017). Dans og kroppsøvingsfaget. Fournal for Research in Arts and Sports Education, 1(3), 61-74. http://dx.doi.org/10.23865/jased.v1.576

Rønholt, H. (2014). Handlekompetence som dannelsesideal. I H. Rønholt \& B. Peitersen (Red.), Idrctsundervisning: En grundbog $i$ idrcetsdidaktik (s. 54-66). København: Museum Tusculanum.

Salmond, M. (2010). The Power of Momentary Communities: Locative Media and (In)Formal Protest. Aether: The fournal of Media Geography, Vol. V.A. 90-100.

Sandseter, E. B. H. (2010). Scaryfunny. A qualitative study of risky play among preschool children. (Doktoravhandling). Norges teknisk-vitenskapelige universitet, Trondheim.

Utdanningsdirektoratet [Udir] (2015). Lcereplan i kroppsøving (KRO1-04). Hentet fra, https://www.udir. no/k106/KRO1-04/Hele/Hovedomraader

van Manen, M. (2014). Phenomenology of practice: meaning-giving methods in phenomenological research and writing. California: Left Coast Press.

van Manen, M. (1990). Researching lived experience. Human science for an action sensitive pedagogy. Ontario: Althouse Press.

Winther, H. (2008). Kroppsbasis. I H. Rønholt, \& B. Peitersen (Red.), Idrcetsundervisning: En grundbog $i$ idrcetsdidaktik (s. 207-241). København: Museum Tusculanum. 


\section{Flashmob i lererutdanninger - studenters erfaringer med å skape dans sammen}

Winther, H. (2012). Det professionspersonlige - om kroppen som klangbund i professionel kommunikation. I H. Winther (Red.), Kroppens sprog $i$ professional praksis. Om kontakt, ncerver, lederskab og personlig kommunikation (s. 74-88). Værløse: Billesø \& Baltzer.

Winther, H., \& de Jong, M. (2016). Grundläggande känslors liv och funktion i undervisning i idrott och rörelse en ständig möjlighet till lärande. idrottsforum.org, 1-20. Hentet fra https://idrottsforum.org/winther160420/ 